\title{
Microdochium albescens may affect the physiological quality of irrigated rice cultivar seeds
}

\author{
Bruno Tabarelli Scheidt ${ }^{1 *}$ (D) Jaquelini Garcia1 ${ }^{1}$ (D) \\ Ricardo Trezzi Casa ${ }^{1}$ (iD) Cileide Maria Medeiros Coelhot ${ }^{1}$
}

${ }^{1}$ Programa de Pós-graduação em Produção Vegetal (PPGPV), Universidade do Estado de Santa Catarina (UDESC), 88520-000, Lages, SC, Brasil. E-mail: brunotabarelli.s@hotmail.com. ${ }^{*}$ Corresponding author.

ABSTRACT: Knowledge of the effect of the seedborne inoculum is important for knowing the level of tolerance of the pathogen by the seed. This research evaluated the effect of the incidence of the fungus Microdochium albescens on the physiological quality of the seeds of different cultivars of irrigated rice. The study was carried out in the seed testing laboratory (STL), phytopathology laboratory and in greenhouse, located at the Center of Agroveterinary Sciences of the Santa Catarina State University, Lages, SC, Brazil. Seeds from six irrigated rice cultivars produced in the Alto Vale do Itajai Region in the 2016/17 harvest, were used. The lots were submitted to the seed health test, identifying four lots per cultivar with a natural incidence of $M$. albescens, with two lots of each cultivar with an incidence greater than $40 \%$ and two lots equal or less than 40\%, totaling 24 seed lots. The following evaluations were carried out on the lots: germination, accelerated aging test, emergence in a greenhouse at 14 days, emergence speed index (ESI), emergence speed (ES), shoot length, root length and fresh and dry mass. There was a significant interaction between cultivar and level of incidence only in the variables germination, vigor and root length. Fresh mass, shoot length and ESI were not affected, regardless of cultivar and incidence of fungus in the seed. The irrigated rice cultivars SCS118 Marquês and SCSBRS Tio Taka are susceptible to a high incidence (> 40\%) of the fungus M. allbescens.

Key words: germination, Oryza sativa, seed pathology, vigor.

\section{Microdochium albescens pode afetar a qualidade fisiológica de sementes de} cultivares de arroz irrigado

RESUMO: O conhecimento do efeito do inóculo na semente é importante para conhecimento do nível de tolerância do patógeno pela semente. Objetivo deste trabalho foi avaliar o efeito da incidencia do fungo Microdochium allbescens sobre a qualidade fisiológica das sementes de diferentes cultivares de arroz irrigado. O estudo foi realizado nos laboratórios de análises de sementes (LAS), fitopatologia e na casa de vegetação, localizados no Centro de Ciências Agroveterinárias da Universidade do Estado de Santa Catarina, Lages, SC. Utilizaram-se sementes de seis cultivares de arroz irrigado produzidas na Região do Alto Vale do Itajai na safra 2016/17. Os lotes foram submetidos ao teste de sanidade de sementes, identificando-se quatro lotes por cultivar com incidencia natural de M. albescens, sendo designados dois lotes de cada cultivar com incidência superior a 40\% e dois lotes igual ou inferior a 40\%, totalizando 24 lotes de sementes. Foram realizadas as seguintes avaliações nos lotes: germinação, teste de envelhecimento acelerado, emergência em casa de vegetação aos 14 dias, indice de velocidade de emergência (IVE), velocidade de emergência (VE), comprimento de parte aérea, comprimento de raiz e massa seca. Houve interação significativa entre cultivar e nivel de incidência apenas nas variáveis germinação, vigor e comprimento de raiz. A massa fresca, comprimento da parte aérea e IVE não foram afetados, independente do cultivar e incidência do fungo na semente. Os cultivares de arroz irrigado SCS118 Marquês e SCSBRS Tio Taka são suscetíveis à alta incidência (> 40\%) do fungo M. albescens.

Palavras-chave: germinação, Oryza sativa, patologia de sementes, vigor.

Despite the productivity levels of irrigated rice in the state of Santa Catarina being among the highest in Brazil, in some years there is a decrease in yield due to adverse climatic and meteorological conditions that favor the occurrence of diseases (SOSBAI, 2018).

In southern Brazil, diseases known as brown spot (Bipolaris oryzae (Breda de Haan) Shoem) and scald (Microdochium albescens Thüm (Syn. Microdochium oryzae Hashioka \& Yokogi; Gerlachia oryzae Hashioka \& Yokogi) it has occurred with greater frequency (CELMER et al., 2007; LUDWIG et al., 2009).
The seeds are considered a source of primary inoculum (WEBSTER \& GUNNELL, 1992), and are responsible for the dissemination of innumerable pathogens that cause important diseases in the rice culture (SILVA et al., 2014). Microdochium albescens is transmitted from seed to irrigated rice seedling (SCHEIDT et al., 2020) causing discoloration in the seedlings (GUTIERREZ et al., 2009).

Despite that, currently the importance of the health quality of rice seeds is underestimated due to the scarcity of studies that prove the real impact on the physiological quality and the performance of seedlings. 
Health tests for irrigated rice seeds from Santa Catarina crops in the 2015 to 2018 harvests, carried out at the Phytopathology Laboratory of the Santa Catarina State University (CAV / UDESC) revealed a prevalence of $100 \%$ and an average incidence greater than $50 \%$ of M. albescens (data in press).

Therefore, the knowledge of the effect of the inoculum on the seed is important to know the level of tolerance of the pathogen by the seed and how much it compromises the performance of the seedlings. Therefore, this research evaluated the effect of the incidence of the fungus $M$. allbescens on the physiological quality of seeds of different cultivars of irrigated rice.

The study was carried out in the seed testing laboratory (STL) and in the greenhouse, located at the Center of Agroveterinary Sciences of the Santa Catarina State University, Lages, SC, Brazil. Seeds of cultivars SCSBRS Tio Taka, Epagri 109, SCS116 Satoru, SCS118 Marquês, SCS121 CL and SCS122 Miura were used, produced in the Alto Vale do Itajaí in the 2016/17 harvest and supplied by the cooperative CRAVIL.

Several lots were submitted to the seed health test at the phytopathology laboratory, where the seeds were sown in BSA + A culture medium (Potato-Sucrose-AGAR + Antibiotic $=200 \mathrm{mg} \mathrm{L}^{-1}$ of streptomycin sulfate). Seeds were disinfected with sodium hypochlorite solution (1\%) for two minutes, with a subsequent rinse with distilled and sterile water. For each batch, four replicates of 100 seeds were analyzed. The seeds were placed in acrylic Petri dishes and kept in growth chambers for seven to ten days at $25^{\circ} \mathrm{C}$ and 12 hours photoperiod. Subsequently, four plots per cultivar with a natural incidence of M. albescens were identified, with two lots of each cultivar having an incidence greater than $40 \%$ and two lots equal to or less than $40 \%$.

The general average incidence of lots below and above $40 \%$ were 30.5 and $84.0 \%$ (SCSBRS Tio Taka), 27.0 and 85.5\% (Epagri 109), 30.5 and $84.5 \%$ (SCS116 Satoru), 14.0 and $70.0 \%$ (SCS118 Marquês), $16.0 \%$ and $73.0 \%$ (SCS121CL), 23.0\% and $42.5 \%$ (SCS122 Miura).

For physiological quality tests carried out in STL, the seeds were initially disinfected in $1.5 \%$ sodium hypochlorite solution for 3 minutes, followed by washing with sterile water. Germination was performed with four replications of 100 seeds for each cultivar and incidence lower and higher than $40 \%$ of the fungus in the seed, on germitest paper moistened three times the weight of the dry paper, and taken to the germinator at $25^{\circ} \mathrm{C}$ (BRASIL, 2009).
The first count occurred at seven days and the final count at the fourteenth day, after sowing. At the end of the test, the number of normal seedlings, abnormal seedlings and dead seeds was recorded.

The accelerated aging test was conducted in germination boxes, using four replicates of 100 seeds for each cultivar, these separated into lots with an incidence above and below $40 \%$ of the fungus $M$. albescens. The seeds were arranged on a stainless steel grid over $40 \mathrm{~mL}$ of distilled and deionized water inside the gerbox boxes and kept in an accelerated aging chamber at $41^{\circ} \mathrm{C}$ for 120 hours (ZUCHI \& BEVILAQUA, 2012). After that period, the seeds were disinfected and distributed in rolls of germitest paper, moistened with water three times its dry weight, and kept in a germinator at $25^{\circ} \mathrm{C}$ (KRZYZANOWSKI et al., 1991). Next, these same seeds were submitted to germination testing as described above.

The greenhouse emergence consisted of sowing four repetitions of 50 pre-germinated seeds of each cultivar and incidence in trays containing $5 \mathrm{~cm}$ of water. Pre-germination was performed by imbibing the seeds in water for 36 hours, followed by another 36 hours in the shade until growth stage "S2" (SOSBAI, 2018). The emergence index (EI), emergence speed (ES), emergence percentage at 14 days (E), shoot and root length and fresh and dry mass were evaluated.

The emergence index (EI) was determined by counting the number of emerged seedlings at the same time every day. At the end of the test, EI was calculated using Maguire's formula (1962).

$E I=\frac{G_{1}}{N_{1}}+\frac{G_{2}}{N_{2}}+\frac{G_{n}}{N_{n}}$

where: $\mathrm{EI}=$ emergence index; $\mathrm{G}=$ number of seedlings observed at each count; $\mathrm{N}=$ number of days from planting to counting.

The formula was applied for each repetition and the arithmetic mean was calculated after all the tests to obtain the EI of the seed lot. The evaluation of seed emergence can follow a dimension less proportionality

The emergence speed (ES) was also calculated based on the number of emerged seedlings observed at the same time every day, using the formula proposed by Edmond \& Drapala (1958):

$E S=\frac{\left(N_{1} G_{1}\right)+\left(N_{2} G_{2}\right)+\ldots+\left(N_{n} G_{n}\right)}{G_{1}+G_{2}+G_{n}}$

where: $E S=$ emergence speed (days); $G=$ number of seedlings observed at each count; $\mathrm{N}=$ number of days from planting to counting. The result was expressed in days. 
Shoot and root length were measured in 20 plants per repetition using a digital pachymeter and the results expressed in millimeters. And after was determined the fresh mass plants through weighing on a scale and dry mass in an oven at $50^{\circ} \mathrm{C}$ for 48 hours, which were then weighed, and the results expressed in grams.

The experimental design used was completely randomized in a factorial arrangement. The germination and ESI averages were transformed by logRatio and chi-square, respectively, to meet homogeneity. Subsequently, they were subjected to Tukey test (5\% significance) using the R software (R CORE TEAM, 2017), version 3.5.1.

There was a significant interaction between cultivars and level of incidence in the variables germination, vigor and root length. Germination of the lots with an incidence of fungus in the seed greater than $40 \%$ varied from $78 \%$ to $90 \%$, while the lots with an incidence equal to or less than $40 \%$ varied from $82 \%$ to $89 \%$. The cultivars SCSBRS Tio Taka and SCS118 Marquês had their germination affected negatively, differing statistically, presenting $78 \%$ and $81 \%$, respectively (Table 1 ).
In the other cultivars there was no effect on the level of incidence of the pathogen. Unlike what was observed by PRABHU \& VIEIRA (1989) who reported that the intensity of brown spot on seeds affects germination, presenting a negative linear relationship. MALAVOLTA et al. (2002) also observed that $B$. oryzae causing the brown spot negatively affects the germination of rice seeds.

The vigor due to accelerated aging of the lots with an incidence of fungus in the seed greater than $40 \%$ varied from $71 \%$ to $83 \%$, while in the lots with an incidence equal to or less than $40 \%$ it varied between $63 \%$ to $85 \%$. Only the cultivars SCS116 Satoru and SCS109 Epagri differed statistically, presenting $63 \%$ and $75 \%$ vigor, respectively, in the incidence of the fungus equal to or less than $40 \%$ (Table 1). This behavior may have occurred if the pathogen has infected a region close to the embryo, which would affect the performance of these seeds.

The greenhouse emergence of cultivars with an incidence of fungus in the seed greater than $40 \%$ varied from $99 \%$ to $95 \%$, while in lots with an incidence equal to or less than $40 \%$, they presented around $98 \%$. Only the cultivar SCSBRS Tio Taka

Table 1 - Physiological performance and rice seedlings ${ }^{1}$ with different levels of incidence the fungus Microdochium albescens.

\begin{tabular}{|c|c|c|c|c|c|c|c|c|c|}
\hline Cultivar & IS & G (\%) & AA (\%) & E (\%) & FM (gr) & $\mathrm{SL}(\mathrm{cm})$ & $\mathrm{RL}(\mathrm{cm})$ & EI & ES (days) \\
\hline \multirow{2}{*}{$\begin{array}{l}\text { SCS122 } \\
\text { Miura }\end{array}$} & $>40 \%$ & $83 a^{2}$ & $78 \mathrm{a}$ & 99 a & $1.3 \mathrm{~ns}$ & $22.4 \mathrm{~ns}$ & $11.6 \mathrm{a}$ & $40.2 \mathrm{~ns}$ & $1.5 \mathrm{a}$ \\
\hline & $\leq 40 \%$ & $82 \mathrm{a}$ & $81 \mathrm{a}$ & $100 \mathrm{a}$ & $1.2 \mathrm{~ns}$ & $22.2 \mathrm{~ns}$ & $11.4 \mathrm{a}$ & $43.0 \mathrm{~ns}$ & $1.3 \mathrm{a}$ \\
\hline \multirow{2}{*}{$\begin{array}{l}\text { SCS118 } \\
\text { Marquês }\end{array}$} & $>40 \%$ & $78 \mathrm{~b}$ & $81 \mathrm{a}$ & 99 a & $1.3 \mathrm{~ns}$ & $23.3 \mathrm{~ns}$ & $13.5 \mathrm{a}$ & $42.5 \mathrm{~ns}$ & $1.3 \mathrm{~b}$ \\
\hline & $\leq 40 \%$ & $82 \mathrm{a}$ & $79 a$ & $98 \mathrm{a}$ & $1.1 \mathrm{~ns}$ & $22.5 \mathrm{~ns}$ & $12.1 \mathrm{a}$ & $37.2 \mathrm{~ns}$ & $1.6 \mathrm{a}$ \\
\hline \multirow{2}{*}{$\begin{array}{l}\text { SCSBRS } \\
\text { Tio Taka }\end{array}$} & $>40 \%$ & $81 \mathrm{~b}$ & 83 a & $95 \mathrm{~b}$ & $1.1 \mathrm{~ns}$ & $22.1 \mathrm{~ns}$ & $10.1 \mathrm{~b}$ & $38.9 \mathrm{~ns}$ & $1.6 \mathrm{~b}$ \\
\hline & $\leq 40 \%$ & $84 \mathrm{a}$ & $82 \mathrm{a}$ & $99 \mathrm{a}$ & $1.1 \mathrm{~ns}$ & $23.0 \mathrm{~ns}$ & $12.8 \mathrm{a}$ & $33.6 \mathrm{~ns}$ & $1.9 \mathrm{a}$ \\
\hline \multirow{2}{*}{$\begin{array}{l}\text { SCS121 } \\
\text { ClearField }\end{array}$} & $>40 \%$ & $83 a$ & 83 a & $97 \mathrm{a}$ & $1.2 \mathrm{~ns}$ & $22.6 \mathrm{~ns}$ & $11.2 \mathrm{a}$ & $37.2 \mathrm{~ns}$ & $1.6 \mathrm{a}$ \\
\hline & $\leq 40 \%$ & 89 a & $85 \mathrm{a}$ & $99 \mathrm{a}$ & $1.1 \mathrm{~ns}$ & $24.1 \mathrm{~ns}$ & $10.2 \mathrm{a}$ & $37.8 \mathrm{~ns}$ & $1.6 \mathrm{a}$ \\
\hline \multirow{2}{*}{$\begin{array}{l}\text { SCS116 } \\
\text { Satoru }\end{array}$} & $>40 \%$ & $87 \mathrm{a}$ & $71 \mathrm{a}$ & $100 \mathrm{a}$ & $1.2 \mathrm{~ns}$ & $24.5 \mathrm{~ns}$ & $10.6 \mathrm{a}$ & $35.2 \mathrm{~ns}$ & $1.7 \mathrm{a}$ \\
\hline & $\leq 40 \%$ & $85 \mathrm{a}$ & $63 \mathrm{~b}$ & 99 a & $1.2 \mathrm{~ns}$ & $22.9 \mathrm{~ns}$ & $10.2 \mathrm{a}$ & $35.9 \mathrm{~ns}$ & $1.6 \mathrm{a}$ \\
\hline \multirow{3}{*}{$\begin{array}{l}\text { SCS109 } \\
\text { Epagri }\end{array}$} & $>40 \%$ & $90 \mathrm{a}$ & 83 a & $99 \mathrm{a}$ & $1.3 \mathrm{~ns}$ & $22.0 \mathrm{~ns}$ & $12.6 \mathrm{a}$ & $38.1 \mathrm{~ns}$ & $1.6 \mathrm{a}$ \\
\hline & $\leq 40 \%$ & $87 \mathrm{a}$ & $75 \mathrm{~b}$ & $98 \mathrm{a}$ & $1.3 \mathrm{~ns}$ & $23.0 \mathrm{~ns}$ & $11.7 \mathrm{a}$ & $35.4 \mathrm{~ns}$ & $1.7 \mathrm{a}$ \\
\hline & CV (\%) & 7.1 & 7.2 & 2.8 & 17.0 & 9.0 & 16.2 & 11.8 & 17.7 \\
\hline
\end{tabular}

${ }^{1}$ IS (Incidence in the seed); G (Germination); AA (vigor by accelerated aging); E (Emergence); FM (fresh mass); SL (Shoot length); RL (Root length); EI (emergence index); ES (Emergence speed).

${ }^{2}$ Means followed by the small letter in the column do not differ in the cultivar by the Tukey test at $5 \%$. 
was negatively affected, with $95 \%$ emergence in an incidence greater than $40 \%$ (Table 1 ).

As observed in the cultivars SCS118 Marquês and SCSBRS Tio Taka, the presence of certain pathogens in the seeds can result in direct effects, such as a reduction in germination potential, vigor, emergence, storage period and even yield (ITO \& TANAKA, 1993).

However, for the other cultivars there was no influence of the incidence of the pathogen on the physiological quality. As the fungus $M$. albescens has a greater capacity to infect the endosperm than the embryo (MANANDHAR, 1999; SCHEIDT, 2020 (data in press), which is the vital part of the seed, it manages to develop and form a normal seedling.

Fresh mass, shoot length and emergence index were not affected, regardless of the cultivar and incidence of the fungus in the seed (Table 1). Similar to that observed by MALAVOLTA et al. (2007) who also did not observe a significant difference in the height of seedlings infected with $B$. oryzae.

The root length in cultivar SCSBRS Tio Taka was compromised, differing statistically and showing a reduction to $10 \mathrm{~cm}$ of root in the incidence of the fungus in the seed above $40 \%$ (Table 1), indicating that the pathogen, in this case, limited the development of the seedling root, possibly due to its location in the seed.

The cultivars SCS118 Marquês and SCSBRS Tio Taka differed statistically in the emergence speed in the level of incidence of the fungus in the seed greater than $40 \%$, presenting approximately 1.3 and 1.6 days respectively to emerge (Table 1). In these cultivars, the colonization of $M$. albescens in the seed endosperm may have been a physical barrier to seedling development, limiting the length of the root. However, there is an influence of the level of incidence of the pathogen $M$. albescens in the seed on the physiological quality.

\section{ACKNOWLEDGEMENTS}

The reserach was financed in part by the Coordenação de Aperfeiçoamento de Pessoal de Nível Superior (CAPES), Brasil, Finance code 001. JG has scholarship from Fundo de Apoio à Manutenção e ao Desenvolvimento da Educação Superior (FUMDES).

\section{DECLARATION OF CONFLICT OF INTEREST}

The authors declare no conflict of interest. The founding sponsors had no role in the design of the study; in the collection, analyses, or interpretation of data; in the writing of the manuscript, and in the decision to publish the results.

\section{AUTHORS' CONTRIBUTIONS}

BTS and RTC conceived and designed experiments. BTS and JG performed the experiments and the lab analyses. CMMC e JG performed statistical analyses of experimental data. BTS and JG prepared the draft of the manuscript. All authors critically revised the manuscript and approved of the final version.

\section{REFERENCES}

CELMER, A. et al. Chemical control of irrigated rice diseases. Pesquisa agropecuária brasileira. v.42, p.901-904, 2007. Available from: <https://doi.org/10.1590/S0100204X200700 060 0019>. Accessed: Mar. 10, 2020. doi: 10.1590/S0100204X2007000600019.

BRASIL. Ministério da Agricultura Pecuária e Abastecimento. Teste de sanidade de sementes. In: Regras para a análise de sementes. Brasília: MAPA/ACS, 2009, Cap.9, p.335-340.

EDMOND, J. B.; DRAPALA, W.J. The effects of temperature, sand and soil, and acetone on germination of okra seeds. Proceedings of American Society of Horticultural Science. v.71, p.428-434, 1958.

GUTIERREZ, S. A. et al. Estudio preliminar sobre métodos de detección de Microdochium oryzae en semillas de arroz. Tropical plant pathology. v.34, p.42-44, 2009. Available from: <https:// doi.org/10.1590/S1982-56762009000100007>. Accessed: Jan. 20, 2020. doi: 10.1590/S1982-56762009000100007.

ITO, M. F.; TANAKA, M. A. S. Soja - Principais doenças causadas por fungos, bactérias e nematóides. Campinas: Fundação Cargil, 1993. p.1-2.

KRZYZANOWSKI, F. C. et al. Relato dos testes de vigor disponíveis para as grandes culturas. Informativo ABRATES, 1991. p.15-50

LUDWIG, J. et al. Seed microbiolization for the control of rice brown spot and leaf scald. Tropical plant pathology. v.34, p.322328, 2009. Available from: <http://www.scielo. br/pdf/tpp/v34n5/ v34n5a05.pdf>. Accessed: Mar. 12, 2020. doi: 10.1590/S198256762009000500005 .

MAGUIRE, J. D. Speeds of germination-aid selection and evaluation for seedling emergence and vigor. Crop Science. v.2, p.176-7, 1962. Available from: <http://dx.doi.org/10.2135/ cropsc i1962.0011183X000200020033x>. Accessed: Feb. 23, 2020. doi: 10.2135/cropsci1962.0011183X000200020033x.

MALAVOLTA, V. M. A. et al. Effect of different incidence levels of Bipolaris oryzae in rice seeds on physiological aspects, seedseedling transmission and production. Summa Phytopathologica. v. 28, 336-340.2002.

MALAVOLTA, V.M.A. et al. Incidência de fungos e quantificação de danos em sementes de genótipos de arroz. Summa Phytopathology. v.33, p.280-286, 2007. Available from: <https:// doi.org/10.1590/S0100-54052007000300012>. Accessed: Mar. 12, 2020. doi: 10.1590/ S0100-54052007000300012.

MANANDHAR, J. B. Isolation of Microdochium oryzae and Pinatubo oryzae from rice seeds and their survival on stored seeds. European Journal of Plant Pathology. v.105, p.139- 
145, 1999. Available from: https://link.springer.com/article /10.1023/A:1008765523465. Accessed: Aug. 02, 2018. doi: 10.1023/A:100876552.

PRABHU, A. S.; VIEIRA, N. R. de. Sementes de arroz infectadas por Drechslera oryzae: germinação, transmissão e controle. Embrapa, Goiânia.1989. Boletim de pesquisa. N.7.

R CORE TEAM. R: A language and environment for statistical computing. R Foundation for Statistical Computing, Vienna, Áustria, 2017.

SCHEIDT, B. T. et al. Transmission of Microdochium albescens from seeds to seedlings in the pre-germinated cultivation system of irrigated rice. Ciência Rural. v.50, e20180898, 2020. Available from: < https://doi.org/10.1590/0103-8478cr20180898>. Accessed: Feb. 21, 2020. doi: 10.1590/0103-8478cr20180898.
SILVA, M. S. B. S. et al. Sanity of rice seed, biocontrol, characterization and transmission of Curvularia lunata on rice seed-seedlings. Revista Ceres. v. 61, p.511-517, 2014. Available from: $\quad<$ https://doi.org/10.1590/0034-737X201461040009>. Accessed: Feb. 11, 2020. doi: 10.1590/0034-737X201461040009.

SOSBAI. Arroz irrigado: recomendações técnicas da pesquisa para o Sul do Brasil. In: XXXII Reunião Técnica da Cultura do Arroz Irrigado. Farroupilha, RS. Cachoeirinha: Sociedade SulBrasileira de Arroz Irrigado, 2018. 205p.

ZUCHI, J.; BEVILAQUA, G. A. P. Qualidade fisiológica de sementes de arroz armazenadas em diferentes embalagens e temperaturas. Boletim de Pesquisa e Desenvolvimento 163. Pelotas, RS 2012. ISSN 1678-2518, dezembro, 2012.

WEBSTER, R. K.; GUNNELL, P. S. Compendium of rice diseases. (The American Phytopathological Society: St. Paul, MN, 1992. 92p. 